\title{
Postnatal Hydrocortisone for Preventing or Treating Bronchopulmonary Dysplasia in Preterm Infants: A Systematic Review
}

\author{
Lex W. Doyle $^{a}$ Richard A. Ehrenkranz ${ }^{b}$ Henry L. Halliday ${ }^{c}$ \\ a Departments of Obstetrics and Gynaecology, and Paediatrics, University of Melbourne, Royal Women's Hospital, \\ and Murdoch Children's Research Institute, Parkville, Vic., Australia; ${ }^{b}$ Department of Pediatrics, Yale University \\ School of Medicine, New Haven, Conn., USA; ' Department of Child Health, Queen's University Belfast, and \\ Perinatal Medicine, Royal Jubilee Maternity Service, Belfast, UK
}

\section{Key Words}

Hydrocortisone - Bronchopulmonary dysplasia •

Bronchopulmonary dysplasia treatment, infants $\cdot$ Mortality rate $\cdot$ Cerebral palsy

\begin{abstract}
Background: Corticosteroids have been used widely after birth in preterm infants with respiratory failure; hydrocortisone may be preferable to other corticosteroids for this purpose. Objectives: To determine if postnatal hydrocortisone is useful to prevent or treat bronchopulmonary dysplasia (BPD) in preterm infants. Methods: Randomised controlled trials (RCTs) of postnatal hydrocortisone therapy to prevent or treat BPD were sought. Data regarding clinical outcomes including mortality, BPD, death or BPD, complications during the primary hospitalisation, and long-term outcome were abstracted and analysed using RevMan 5. Results: Eight RCTs enrolling a total of 880 participants were eligible. In all trials treatment was started in the first week of life; there were no trials of treatment started in infants who were chronically ventilator-dependent after the first week of life with established or evolving BPD. A meta-analysis of the available trials demonstrated little evidence for a direct ef-
\end{abstract}

fect of hydrocortisone on the rates of BPD, mortality, or the combined outcome of BPD or mortality. Hydrocortisone in the doses used in these eight studies had few beneficial or harmful effects; the notable exception was an increase in gastrointestinal perforation. Conclusions: Postnatal hydrocortisone in the doses and regimens used in the reported trials has few beneficial or harmful effects and cannot be recommended for prevention of BPD. There are no randomised trials to substantiate the use of hydrocortisone in chronically ventilator-dependent infants with established or evolving BPD.

Copyright $\odot 2010$ S. Karger AG, Basel

\section{Background}

Corticosteroids to treat or prevent bronchopulmonary dysplasia (BPD) are controversial [1]. Recent articles have suggested hydrocortisone as a safer alternative to dexamethasone in treating or preventing BPD [2], partly on

Supported in part by Project Grant No. 108700 from the National Health and Medical Research Council, Australia.

\section{KARGER}

Fax +41613061234 E-Mail karger@karger.ch www.karger.com
(C) 2010 S. Karger AG, Basel

$1661-7800 / 10 / 0982-0111 \$ 26.00 / 0$

Accessible online at:

www.karger.com/neo
Prof. Lex W. Doyle

Department of Obstetrics and Gynaecology, The Royal Women's Hospital

20 Flemington Rd

Parkville, Vic. 3052 (Australia)

Tel. +61 38345 3716, Fax +61 38345 3702, E-Mail lwd@ unimelb.edu.au 
the basis of data from observational long-term studies of fewer adverse behavioural [3], cardiovascular [4], neurological and immune [5] outcomes, among others, in childhood [6]. This view is supported by animal evidence of fewer changes in the hypothalamus of adolescent rats exposed as neonates to hydrocortisone compared with dexamethasone [7]. However, the use of hydrocortisone in clinical practice needs to be substantiated by experimental data in humans.

The aim of this study was to review systematically the data from randomised controlled trials (RCTs) in newborn infants where hydrocortisone was compared with placebo, to establish the balance between risks and benefits of hydrocortisone in newborn infants in the prevention or treatment of BPD.

\section{Methods}

We included all RCTs of postnatal hydrocortisone therapy in preterm infants to treat or prevent BPD, where the comparison treatment was placebo. Trials using hydrocortisone in the first days of life were included even if it had been used primarily to treat or prevent hypotension, as long as outcomes included BPD, mortality or cerebral palsy. Studies included preterm infants who were ventilator-dependent at entry. The type of intervention included intravenous or oral hydrocortisone versus control (placebo or no treatment). The types of outcome measures included mortality, BPD (oxygen requirement at 36 weeks' postmenstrual age; PMA), death or BPD, late rescue with corticosteroids, survivors discharged home on oxygen, failure to extubate, complications during the primary hospitalisation (including infection, hyperglycaemia, hypertension, pulmonary air leak, patent ductus arteriosus (PDA), severe intraventricular haemorrhage (IVH), periventricular leukomalacia (PVL), necrotising enterocolitis (NEC), gastrointestinal (GI) bleeding, GI perforation, severe retinopathy of prematurity (ROP), and long-term outcomes (including cerebral palsy).

RCTs of postnatal hydrocortisone therapy were sought from the Cochrane Controlled Trials Register (CENTRAL), MEDLINE, hand-searching paediatric and perinatal journals, examining previous review articles and information received from practising neonatologists. MEDLINE was searched from 1966 through March 2009 using the terms: cortisone or hydrocortisone, limits randomised controlled trials, human, all infant: birth-23 months.

For each trial, information was sought regarding the method of randomisation, blinding, stratification, and reporting of the outcome of all the infants enrolled. Information on the trial participants included the need for mechanical ventilation and the age when treatment was started. Outcomes included those listed above. Meta-analysis of the included trials was performed using RevMan 5. For some statistically and clinically significant outcomes the number needed to treat for additional beneficial (NNTB) or harmful (NNTH) outcomes and 95\% confidence intervals (CIs) were calculated from the typical relative risks ac- cording to methods of the Cochrane Handbook for Systematic Reviews of Interventions [8], assuming the control group event rate as the baseline rate. Significant heterogeneity was present if the $\mathrm{I}^{2}$ statistic exceeded $50 \%$, suggesting caution when interpreting the results of meta-analysis. In a sensitivity analysis the main outcomes were re-analysed limited to studies where the primary aim was to prevent BPD.

\section{Results}

Eight trials qualified for inclusion in this review [916]. Most of the trials enrolled low birth weight or very preterm babies with respiratory distress syndrome (RDS) who were receiving mechanical ventilation; other characteristics are listed in table 1 . In most trials the primary aim of the study was to prevent BPD $[10-12,14,16]$; in two the intent was to treat hypotension $[13,17]$, and the original trial reported in 1972 [9] was primarily aiming to test the effects of hydrocortisone on acute RDS. In all studies, treatment started within the first week of life, although the treatment course in some cases lasted into the second week of life; there were no trials of treatment started in infants who were chronically ventilator-dependent after the first week of life with established or evolving BPD. All were methodologically sound trials; all were randomised trials, with treatment allocation concealed from the study investigators, blinding of intervention from the investigators by use of placebos, blinding of outcome measures, and complete reporting of in-hospital outcomes for infants randomised, and high follow-up rates (at least $85 \%$ ) for centres reporting outcomes beyond discharge.

Apart from the original trial reported in 1972 [9] where the total dose was $30 \mathrm{mg} / \mathrm{kg}$ on day 1 of life, most other regimens had lower total doses, ranging from 5 to $15 \mathrm{mg} / \mathrm{kg}$ over 5-15 days (table 1), and could be considered either 'physiological' or 'stress' doses of hydrocortisone, particularly when the primary indication was the management of hypotension.

In each study the numbers enrolled within the respective groups and the numbers with major outcomes of death, BPD and cerebral palsy, and combined outcomes of death or BPD, and death or cerebral palsy are shown in table 2 .

\section{Results of Meta-Analysis}

Meta-analysis of these eight studies of hydrocortisone treatment showed the following results: 
Table 1. Types of subjects and hydrocortisone regimens

\begin{tabular}{|c|c|c|c|c|}
\hline $\begin{array}{l}\text { First author, year } \\
\text { [reference] }\end{array}$ & $\begin{array}{l}\text { Number of subjects and } \\
\text { study summary }\end{array}$ & Hydrocortisone regimen & $\begin{array}{l}\text { Total dose } \\
\mathrm{mg} / \mathrm{kg}\end{array}$ & $\begin{array}{l}\text { Duration } \\
\text { days }\end{array}$ \\
\hline $\begin{array}{l}\text { Baden } \\
1972[9]\end{array}$ & $\begin{array}{l}\mathrm{n}=44 \text { with RDS; BW } 800-2,805 \mathrm{~g} \\
\text { GA } 26-36 \text { weeks; }<24 \text { h of age }\end{array}$ & $\begin{array}{l}15 \mathrm{mg} / \mathrm{kg} \text { on admission and } \\
12 \mathrm{~h} \text { later i.v. }\end{array}$ & 30 & 1 \\
\hline $\begin{array}{l}\text { Watterberg } \\
1999[10]\end{array}$ & $\begin{array}{l}\mathrm{n}=40 \text {; mechanically ventilated; } \\
\text { BW } 500-999 \mathrm{~g} ;<48 \mathrm{~h} \text { of age }\end{array}$ & $\begin{array}{l}1 \mathrm{mg} / \mathrm{kg} / \text { day for } 9 \text { days, then } \\
0.5 \mathrm{mg} / \mathrm{kg} / \text { day for } 3 \text { days }\end{array}$ & 10.5 & 12 \\
\hline $\begin{array}{l}\text { Biswas } \\
2003[11]\end{array}$ & $\begin{array}{l}\mathrm{n}=253 \text {; mechanically ventilated; } \\
<9 \text { h; all given surfactant; GA }<30 \text { weeks }\end{array}$ & $\begin{array}{l}1 \mathrm{mg} / \mathrm{kg} / \mathrm{day} \text { for } 5 \text { days, } \\
\text { then } 0.5 \mathrm{mg} / \mathrm{kg} / \text { day for } 2 \text { days }^{\mathrm{a}}\end{array}$ & 6 & 7 \\
\hline $\begin{array}{l}\text { Watterberg } \\
2004[12]\end{array}$ & $\begin{array}{l}\mathrm{n}=360^{\mathrm{b}} ; \text { mechanically ventilated; } \\
\text { BW } 500-999 \mathrm{~g} ; 12-48 \mathrm{~h} \text { of age }\end{array}$ & $\begin{array}{l}1 \mathrm{mg} / \mathrm{kg} / \text { day for } 12 \text { days, } \\
\text { then } 0.5 \mathrm{mg} / \mathrm{kg} / \text { day for } 3 \text { days }\end{array}$ & 13.5 & 15 \\
\hline $\begin{array}{l}\text { Efird } \\
2005[13]\end{array}$ & $\begin{array}{l}\mathrm{n}=34 \text {; treatment of hypotension; } \\
\mathrm{BW}<1,000 \mathrm{~g} \text { or GA } 24-28 \text { weeks; }<2 \text { h of age }\end{array}$ & $\begin{array}{l}1 \mathrm{mg} / \mathrm{kg} / 12 \mathrm{~h} \text { i.v. for } 2 \text { days, } \\
\text { followed by } 0.3 \mathrm{mg} / \mathrm{kg} / 12 \mathrm{~h} \text { for } 3 \text { days }\end{array}$ & 5.8 & 5 \\
\hline $\begin{array}{l}\text { Peltoniemi } \\
2005[14]\end{array}$ & $\begin{array}{l}\mathrm{n}=51^{\mathrm{c}} \text {; ventilator-dependent; } \\
\text { BW } 501-1,251 \mathrm{~g} \text { or GA } 23-30 \text { weeks; }<36 \text { h old }\end{array}$ & $\begin{array}{l}2 \mathrm{mg} / \mathrm{kg} / \text { day for } 2 \text { days, } 1.5 \mathrm{mg} / \mathrm{kg} / \text { day } \\
\text { for } 2 \text { days, } 0.75 \mathrm{mg} / \mathrm{kg} / \text { day for } 6 \text { days }\end{array}$ & 11.5 & 10 \\
\hline $\begin{array}{l}\mathrm{Ng} \\
2006[15]\end{array}$ & $\begin{array}{l}\mathrm{n}=48 \text {; treatment of hypotension; } \\
\mathrm{BW}<1,500 \mathrm{~g} ;<7 \text { days of age }\end{array}$ & $1 \mathrm{mg} / \mathrm{kg} / 8 \mathrm{~h}$ for 5 days & 15 & 5 \\
\hline $\begin{array}{l}\text { Bonsante } \\
2007[16]\end{array}$ & $\begin{array}{l}\mathrm{n}=50^{\mathrm{c}} ; \text { mechanically ventilated; }<48 \mathrm{~h} \text {; all given } \\
\text { surfactant; } \mathrm{BW}<1,250 \mathrm{~g} \text { or GA } 24-30 \text { weeks }\end{array}$ & $\begin{array}{l}1 \mathrm{mg} / \mathrm{kg} \text { for } 9 \text { days, then } \\
0.5 \mathrm{mg} / \mathrm{kg} / \text { day for } 3 \text { days }\end{array}$ & 10.5 & 12 \\
\hline
\end{tabular}

RDS = Respiratory distress syndrome; BW = birth weight; GA = gestational age.

${ }^{a}$ Also given tri-iodothyronine $6 \mu \mathrm{g} / \mathrm{kg} /$ day for 5 days, then $3 \mu \mathrm{g} / \mathrm{kg} /$ day for 2 days.

$\mathrm{b}$ Trial stopped early because of high rate of intestinal perforation.

${ }^{c}$ Trial stopped early because of high rate of intestinal perforation in other studies, and after several perforations in their own study.

Table 2. Numbers enrolled by group with selected outcomes

\begin{tabular}{|c|c|c|c|c|c|c|c|c|c|c|c|c|}
\hline \multirow{2}{*}{$\begin{array}{l}\text { First author, year } \\
\text { [reference] }\end{array}$} & \multicolumn{2}{|c|}{ Enrolled } & \multicolumn{2}{|c|}{ Mortality $^{\mathrm{a}}$} & \multicolumn{2}{|c|}{$\mathrm{BPD}^{\mathrm{b}}$} & \multicolumn{2}{|c|}{ Death or $\mathrm{BPD}^{\mathrm{c}}$} & \multicolumn{2}{|l|}{$\mathrm{CP}$} & \multicolumn{2}{|c|}{ Death or CP } \\
\hline & $\mathrm{HC}$ & $\mathrm{C}$ & $\mathrm{HC}$ & $\mathrm{C}$ & $\mathrm{HC}$ & $\mathrm{C}$ & $\mathrm{HC}$ & $\mathrm{C}$ & $\mathrm{HC}$ & $\mathrm{C}$ & $\mathrm{HC}$ & $\mathrm{C}$ \\
\hline Baden, 1972 [9]; Fitzhardinge, 1974 [18] & 22 & 22 & 8 & 9 & & & & & 2 & 1 & 10 & 10 \\
\hline $\begin{array}{l}\text { Watterberg, } 1999[10] \text { and } \\
2002 \text { [pers. commun.] }\end{array}$ & 20 & 20 & 3 & 3 & 5 & 10 & 8 & 13 & 1 & 2 & 4 & 4 \\
\hline Biswas, 2003 [11] & 125 & 128 & 23 & 26 & 59 & 56 & 82 & 81 & No & & & \\
\hline Watterberg, 2004 [12] and 2007 [19] & 180 & 180 & 33 & 33 & 90 & 92 & 117 & 120 & 16 & 18 & 49 & 51 \\
\hline Efird, 2005 [13] & 16 & 18 & 2 & 3 & 9 & 8 & 11 & 11 & No & & & \\
\hline Peltoniemi, 2005 [14] and 2008 [20] & 25 & 26 & 2 & 3 & 7 & 11 & 9 & 12 & 2 & 0 & 4 & 3 \\
\hline $\mathrm{Ng}, 2006[15]$ & 24 & 24 & 4 & 3 & 9 & 8 & 13 & 11 & No & & & \\
\hline Bonsante, 2007 [16]; Peltoniemi, 2007 [20] & 25 & 25 & 4 & 10 & 6 & 8 & 9 & 17 & 2 & 2 & 6 & 12 \\
\hline
\end{tabular}

$\mathrm{HC}=$ Hydrocortisone; $\mathrm{C}=$ control; $\mathrm{BPD}=$ bronchopulmonary dysplasia; $\mathrm{CP}=$ cerebral palsy; $\mathrm{No}=$ no follow-up component.

${ }^{a}$ Mortality at latest age. ${ }^{b}$ Oxygen requirement at 36 weeks. ${ }^{c}$ At 36 weeks. 


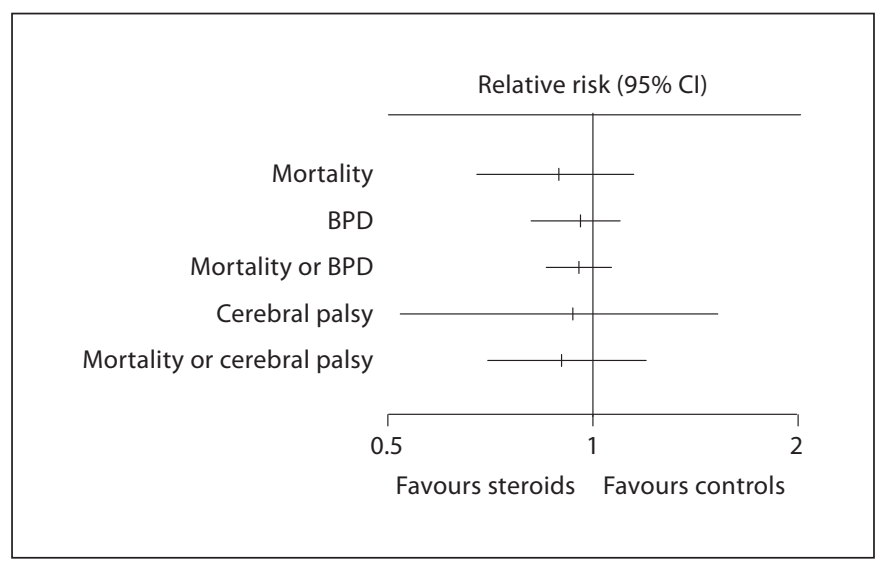

Fig. 1. Forest plot of typical relative risks and 95\% CIs from metaanalysis of mortality, BPD, and cerebral palsy outcomes.

Mortality and Acute Lung Morbidity. There was little evidence that hydrocortisone reduced mortality, the rate of BPD at 36 weeks' PMA, the incidence of death or BPD at 36 weeks' PMA (fig. 1), the proportion of survivors discharged home on oxygen, or the rate of failure to extubate (table 3).

Complications during the Primary Hospitalisation. Hydrocortisone significantly increased the risks of GI perforation (table 3); the number needed to treat to cause one case with GI perforation (NNTH) was 20 (95\% CI $8-151)$. Hydrocortisone reduced the risk of PDA; the number needed to treat to prevent one case with PDA (NNTB) was 14 (95\% CI 8-203). There were no significant effects on NEC, severe IVH, PVL, infection, or severe ROP (table 3).

Follow-Up Data. These were available for five [18-20, and K.L. Watterberg, pers. commun., 2002] of the eight studies; the report by Peltoniemi et al. [20] included follow-up data from the trial of Bonsante et al. [16]. The rates of cerebral palsy or combined mortality or cerebral palsy were not substantially altered by hydrocortisone (fig. 1; table 3).

When meta-analysis was restricted only to studies where the primary goal was to prevent $\mathrm{BPD}$, there was little change to any relative risk or its $95 \% \mathrm{CI}$, and no conclusions were altered (table 3).

Some of the possible outcomes of interest contained few studies and small sample sizes, and hence the power to detect either beneficial or harmful effects of hydrocortisone was limited under these circumstances. Examples included rates of hyperglycaemia (typical relative risk $0.92,95 \%$ CI $0.50-1.67$; one study and 50 infants), hyper- tension (typical relative risk 3.00, 95\% CI 0.33-26.92; one study and 50 infants), and GI haemorrhage (typical relative risk 1.53, 95\% CI 0.27-8.74; two studies and 91 infants).

\section{Discussion}

In this systematic review and meta-analysis of the RCTs of hydrocortisone in preterm neonates, we identified a total of eight trials and in all of these hydrocortisone was started in the first week of life, before BPD is established. In all but one study the dose of hydrocortisone was relatively low. There was little evidence to support the use of hydrocortisone to prevent BPD; there were no improvements in important outcomes of mortality, or of rates of BPD or home oxygen dependence. The significant reduction in the rate of PDA is of doubtful clinical significance in the absence of any effects on mortality or BPD. Moreover, the small gain in the reduction of PDA is probably more than offset by a substantial increase in the rate of spontaneous GI perforation, which may be potentiated by concomitant treatment with indomethacin $[12,14]$. There was little evidence of any other harmful effects of hydrocortisone, including on the rate of cerebral palsy. Restricting the meta-analysis to only those trials where the intent was to prevent BPD had little effect on the results and altered no conclusions.

The situation with hydrocortisone started in the first week of life is in contrast with the effects of dexamethasone started during that time. Dexamethasone substantially facilitates extubation and reduces the rate of BPD and the need for late rescue with corticosteroids [21,22]. Early dexamethasone causes more early complications, such as high blood pressure and blood glucose, GI bleeding, hypertrophic cardiomyopathy, and growth failure, and, like hydrocortisone, also leads to more spontaneous GI perforations [21,22]. Early dexamethasone also causes an increase in cerebral palsy [21, 22]. A possible reason for the differences observed in the RCTs of dexamethasone and those of hydrocortisone is that the doses of hydrocortisone have been much lower than the doses of dexamethasone, in equivalent terms. The typical total dose of hydrocortisone of $5-15 \mathrm{mg} / \mathrm{kg}$ equates to approximately $0.2-0.6 \mathrm{mg} / \mathrm{kg}$ of dexamethasone - all but one of the 20 dexamethasone RCTs used higher total doses than this (up to $14 \mathrm{mg} / \mathrm{kg}$ total in one study) [23]. The power to detect beneficial or harmful effects of hydrocortisone was relatively low compared with the more numerous 
Table 3. Meta-analysis of selected outcomes

\begin{tabular}{|c|c|c|c|c|}
\hline Outcome & Studies & Infants & $\begin{array}{l}\text { Typical relative risk } \\
(95 \% \mathrm{CI})\end{array}$ & $\mathrm{p}$ value \\
\hline \multicolumn{5}{|l|}{ All studies } \\
\hline Mortality at latest reported age & 8 & 880 & $0.89(0.68-1.16)$ & 0.39 \\
\hline $\mathrm{BPD}^{\mathrm{a}}$ & 6 & 802 & $0.96(0.82-1.12)$ & 0.60 \\
\hline Death or $\mathrm{BPD}^{\mathrm{b}}$ & 7 & 836 & $0.95(0.86-1.06)$ & 0.38 \\
\hline Late rescue with corticosteroids & 4 & 509 & $1.01(0.73-1.40)^{\mathrm{c}}$ & 0.97 \\
\hline Discharged home on oxygen & 3 & 285 & $0.66(0.40,1.11)$ & 0.12 \\
\hline \multicolumn{5}{|l|}{ Other early complications } \\
\hline Infection & 5 & 737 & $1.03(0.87-1.21)$ & 0.76 \\
\hline PDA & 6 & 786 & $0.85(0.73-0.99)^{\mathrm{c}}$ & 0.04 \\
\hline Severe IVH & 7 & 836 & $0.92(0.67-1.28)$ & 0.62 \\
\hline PVL & 5 & 762 & $1.07(0.55-2.09)$ & 0.83 \\
\hline NEC & 7 & 836 & $0.84(0.54-1.30)$ & 0.43 \\
\hline Intestinal perforation & 6 & 583 & $2.02(1.13-3.59)$ & 0.02 \\
\hline Severe ROP & 5 & 549 & $0.83(0.60-1.16)$ & 0.28 \\
\hline \multicolumn{5}{|l|}{ Long-term follow-up } \\
\hline Cerebral palsy & 5 & 531 & $0.97(0.55-1.69)$ & 0.91 \\
\hline Death or cerebral palsy & 5 & 531 & $0.91(0.70-1.19)$ & 0.51 \\
\hline \multicolumn{5}{|c|}{ Only studies designed to prevent BPD } \\
\hline Mortality at latest reported age & 5 & 754 & $0.88(0.65-1.18)$ & 0.38 \\
\hline $\mathrm{BPD}^{\mathrm{a}}$ & 5 & 754 & $0.95(0.82-1.11)$ & 0.54 \\
\hline Death or $\mathrm{BPD}^{\mathrm{b}}$ & 5 & 754 & $0.94(0.84-1.05)$ & 0.24 \\
\hline Late rescue with corticosteroids & 3 & 461 & $1.03(0.73-1.46)^{\mathrm{c}}$ & 0.87 \\
\hline Discharged home on oxygen & 3 & 285 & $0.66(0.40-1.11)$ & 0.12 \\
\hline PDA & 5 & 754 & $0.85(0.73-0.99)^{\mathrm{c}}$ & 0.04 \\
\hline Intestinal perforation & 4 & 501 & $2.19(1.18-4.07)$ & 0.01 \\
\hline Cerebral palsy & 4 & 487 & $0.92(0.52-1.64)$ & 0.79 \\
\hline Death or cerebral palsy & 4 & 487 & $0.90(0.68-1.20)$ & 0.48 \\
\hline
\end{tabular}

$\mathrm{CI}=$ Confidence interval; $\mathrm{BPD}=$ bronchopulmonary dysplasia; $\mathrm{PDA}=$ patent ductus arteriosus; $\mathrm{IVH}=$ intraventricular haemorrhage; $\mathrm{PVL}=$ periventricular leukomalacia; $\mathrm{NEC}=$ necrotising enterocolitis; $\mathrm{ROP}=$ retinopathy of prematurity.

${ }^{a}$ Oxygen requirement at 36 weeks. ${ }^{b}$ At 36 weeks. ${ }^{c}$ Significant heterogeneity $\left(\mathrm{I}^{2}>50 \%\right)$.

studies of dexamethasone which have recruited more infants.

What is completely lacking so far are any RCTs of hydrocortisone to treat established ventilator dependence or BPD in infants, starting after the first week of life. Such trials are urgently needed to justify the call for hydrocortisone to be used instead of dexamethasone in these infants [2]. If indeed trials of hydrocortisone are undertaken in ventilator-dependent babies with established lung disease, infants at high risk of BPD should be targeted [24]. Moreover, higher than physiological or stress doses of hydrocortisone may be required. In one study of dexamethasone a total dose of $0.89 \mathrm{mg} / \mathrm{kg}$ over 10 days was successful in weaning from the ventilator [25]. This dose equates to one of approximately $25 \mathrm{mg} / \mathrm{kg}$ of hydrocorti- sone; however, most other studies of dexamethasone have used much higher doses [26]. If indeed higher doses are used, and even if they are not, RCTs of hydrocortisone for infants with established BPD must be powered to detect improvements in survival free of major disability as the major endpoint. Short-term benefits may not be acceptable if offset by long-term harm.

Besides corticosteroids, other ventilatory [27] and non-ventilatory strategies $[28,29]$ must be sought to reduce lung injury and prevent development of BPD, including a re-evaluation of inhaled corticosteroids [30].

We have not attempted subgroup analyses other than by the main indication for treating with hydrocortisone as there were no beneficial effects of hydrocortisone. A subgroup where there are no other corticosteroids pre- 
scribed might be of interest, but apart from the original trial in only 44 infants in 1972 [9] where open-label corticosteroids were unlikely, either they have been used or it is not explicitly stated that they were never used in either group [11, 13]. Open-label steroid prescribing makes it harder to determine the effects of hydrocortisone alone. Other subgroups of interest might include those by gestational age, but this type of analysis is not possible without individual patient data, which are unavailable for all of the trials of hydrocortisone.
In conclusion, there is little evidence to support the use of hydrocortisone as prophylaxis for BPD in the dose regimens employed in the studies reviewed. All RCTs of hydrocortisone should report late outcomes, especially neurological and developmental outcomes, among surviving infants who participated in the studies. Future studies are needed to identify those infants most at risk of either dying or surviving with neurological disability, as a consequence of prolonged assisted ventilation and evolving $\mathrm{BPD}$. It is these high-risk infants who should be the subjects of any future RCTs of hydrocortisone.

\section{References}

1 American Academy of Pediatrics, Committee on Fetus and Newborn, and Canadian Paediatric Society, Fetus and Newborn Committee: Postnatal corticosteroids to treat or prevent chronic lung disease in preterm infants. Pediatrics 2002;109:330-338.

-2 Rademaker KJ, de Vries LS, Uiterwaal CS, Groenendaal F, Grobbee DE, van Bel F: Postnatal hydrocortisone treatment for chronic lung disease in the preterm newborn and long-term neurodevelopmental follow-up. Arch Dis Child Fetal Neonatal Ed 2008;93: F58-F63.

-3 Karemaker R, Heijnen CJ, Veen S, Baerts W, Samsom J, Visser GH, Kavelaars A, van Doornen LJ, van Bel F: Differences in behavioral outcome and motor development at school age after neonatal treatment for chronic lung disease with dexamethasone versus hydrocortisone. Pediatr Res 2006;60: 745-750.

4 Karemaker R, Karemaker JM, Kavelaars A, Tersteeg-Kamperman M, Baerts W, Veen S, Samsom JF, van Bel F, Heijnen CJ: Effects of neonatal dexamethasone treatment on the cardiovascular stress response of children at school age. Pediatrics 2008;122:978-987.

5 Karemaker R, Kavelaars A, ter Wolbeek M, Tersteeg-Kamperman M, Baerts W, Veen S, Samsom JF, Visser GH, van Bel F, Heijnen C): Neonatal dexamethasone treatment for chronic lung disease of prematurity alters the hypothalamus-pituitary-adrenal axis and immune system activity at school age. Pediatrics 2008;121:e870-e878.

6 Rademaker KJ, de Vries WB: Long-term effects of neonatal hydrocortisone treatment for chronic lung disease on the developing brain and heart. Semin Fetal Neonatal Med 2009; 14:171-177.

7 Huang CC, Lin HR, Liang YC, Hsu KS: Effects of neonatal corticosteroid treatment on hippocampal synaptic function. Pediatr Res 2007;62:267-270.
8 Higgins JPT, Green S: Cochrane Handbook for Systematic Reviews of Interventions Version 5.0.0 (updated February 2008). Higgins JPT, Green S (eds): The Cochrane Collaboration, 2008. Available from www.cochranehandbook.org.

$\checkmark 9$ Baden M, Bauer CR, Colle E, Klein G, Taeusch HW Jr, Stern L: A controlled trial of hydrocortisone therapy in infants with respiratory distress syndrome. Pediatrics 1972; 50:526-534.

10 Watterberg KL, Gerdes JS, Gifford KL, Lin HM: Prophylaxis against early adrenal insufficiency to prevent chronic lung disease in premature infants. Pediatrics 1999;104: 1258-1263.

11 Biswas S, Buffery J, Enoch H, Bland M, Markiewicz M, Walters D: Pulmonary effects of triiodothyronine $\left(\mathrm{T}_{3}\right)$ and hydrocortisone (HC) supplementation in preterm infants less than 30 weeks' gestation: results of the THORN trial - thyroid hormone replacement in neonates. Pediatr Res 2003;53:4856.

12 Watterberg KL, Gerdes JS, Cole CH, Aucott SW, Thilo EH, Mammel MC, Couser RJ, Garland JS, Rozycki HJ, Leach CL, Backstrom C, Shaffer ML: Prophylaxis of early adrenal insufficiency to prevent bronchopulmonary dysplasia: a multicenter trial. Pediatrics 2004;114:1649-1657.

13 Efird MM, Heerens AT, Gordon PV, Bose CL, Young DA: A randomized-controlled trial of prophylactic hydrocortisone supplementation for the prevention of hypotension in extremely low birth weight infants. J Perinatol 2005;25:119-124.

14 Peltoniemi O, Kari MA, Heinonen K, Saarela T, Nikolajev K, Andersson S, Voutilainen R, Hallman M: Pretreatment cortisol values may predict responses to hydrocortisone administration for the prevention of bronchopulmonary dysplasia in high-risk infants. J Pediatr 2005;146:632-637.
15 Ng PC, Lee CH, Bnur FL, Chan IH, Lee AW, Wong E, Chan HB, Lam CW, Lee BS, Fok TF: A double-blind, randomized, controlled study of a 'stress dose' of hydrocortisone for rescue treatment of refractory hypotension in preterm infants. Pediatrics 2006;117:367375.

16 Bonsante F, Latorre G, Iacobelli S, Forziati V, Laforgia N, Esposito L, Mautone A: Early low-dose hydrocortisone in very preterm infants: a randomized, placebo-controlled trial. Neonatology 2007;91:217-221.

17 Ng A, Subhedar N, Primhak RA, Shaw NJ: Arterial oxygen saturation profiles in healthy preterm infants. Arch Dis Child Fetal Neonatal Ed 1998;79:F64-F66.

18 Fitzhardinge PM, Eisen A, Lejtenyi C, Metrakos K, Ramsay M: Sequelae of early steroid administration to the newborn infant. Pediatrics 1974;53:877-883.

19 Watterberg KL, Shaffer ML, Mishefske MJ, Leach CL, Mammel MC, Couser RJ, Abbasi S, Cole CH, Aucott SW, Thilo EH, Rozycki HJ, Lacy CB: Growth and neurodevelopmental outcomes after early low-dose hydrocortisone treatment in extremely low birth weight infants. Pediatrics 2007;120:40-48.

20 Peltoniemi OM, Lano A, Puosi R, Yliherva A, Bonsante F, Kari MA, Hallman M: Trial of early neonatal hydrocortisone: two-year follow-up. Neonatology 2008;95:240-247.

21 Halliday HL, Ehrenkranz RA, Doyle LW: Early ( $<8$ days) postnatal corticosteroids for preventing chronic lung disease in preterm infants. Cochrane Database Syst Rev 2009: CD001146.

22 Doyle LW, Halliday HL, Ehrenkranz RA: Dexamethasone treatment in the first week of life for preventing bronchopulmonary dysplasia in preterm infants: a systematic review. Neonatology 2010, in press. 
-23 Halac E, Halac J, Begue EF, Casanas JM, Indiveri DR, Petit JF, Figueroa MJ, Olmas JM, Rodriguez LA, Obregon RJ, et al: Prenatal and postnatal corticosteroid therapy to prevent neonatal necrotizing enterocolitis: a controlled trial. J Pediatr 1990;117:132-138.

-24 Doyle LW, Halliday HL, Ehrenkranz RA, Davis PG, Sinclair JC: Impact of postnatal systemic corticosteroids on mortality and cerebral palsy in preterm infants: effect modification by risk for chronic lung disease. Pediatrics 2005; 115:655-661.
25 Doyle LW, Davis PG, Morley CJ, McPhee A, Carlin JB: Low-dose dexamethasone facilitates extubation among chronically ventilator-dependent infants: a multicenter, international, randomized, controlled trial. Pediatrics 2006;117:75-83.

26 Halliday HL, Ehrenkranz RA, Doyle LW: Late ( $>7$ days) postnatal corticosteroids for chronic lung disease in preterm infants. Cochrane Database Syst Rev 2009:CD001145.

-27 Soll RF: Current trials in the treatment of respiratory failure in preterm infants. Neonatology 2009;95:368-372.

-28 Thomas W, Speer CP: Nonventilatory strategies for prevention and treatment of bronchopulmonary dysplasia - what is the evidence? Neonatology 2008;94:150-159.
29 Schmidt B, Roberts R, Millar D, Kirpalani H: Evidence-based neonatal drug therapy for prevention of bronchopulmonary dysplasia in very-low-birth-weight infants. Neonatology 2008;93:284-287.

-30 Bassler D, Halliday HL, Plavka R, Hallman M, Shinwell ES, Jarreau PH, Carnielli V, van den Anker J, Schwab M, Poets CF: The Neonatal European Study of Inhaled Steroids (NEUROSIS): an EU-funded international randomised controlled trial in preterm infants. Neonatology 2009;97:52-55. 